\title{
Exploration of Chinese Ecological and Environmental Philosophy
}

\author{
Shaoyao HE \\ School of architecture \\ Hunan University \\ Changsha, Hunan, China \\ e-mail: syhe829@163.com
}

\author{
Duo LI \\ School of architecture \\ Hunan University \\ Changsha, Hunan, China \\ e-mail: 191229181@qq.com
}

\author{
Ouyang DUO \\ School of architecture \\ Hunan University \\ Changsha, Hunan, China \\ e-mail: 69237697@qq.com
}

\begin{abstract}
Chinese traditional culture contains rich ecological philosophy thought. This paper focuses on the analysis of the ecological and environmental philosophy of "harmony between man and nature" in Chinese ancient Confucianism and Taoism. It is believed that the thought has important practical guiding function and international reference significance for the construction of ecological civilization in China, and put forward the development strategy of ecological civilization construction.
\end{abstract}

Keywords-ecological environment; harmony between man and nature; confucianism; taoism

\section{INTRODUCTION}

The industrial revolution created a high degree of material civilization; meanwhile, it brought about to human beings such as environmental pollution, population expansion, species extinction, energy depletion and so on, which threatened human survival and development, accelerated the increasing worsening of human survival environment, and triggered off a series of new social problems. Until 1960s, people began to change the mind to reposition the relationship between man and nature and took into consideration the harmonious coexistence of man and nature, and the sustainable development of human beings as the core issue.

Chinese traditional culture contains profound ecological thoughts and wisdom. The study of it will help us to clarify the relationship between man and nature, realize the sustainable development of China, and also will have a profound impact on the global sustainable development.

\section{The PRimitive EColOgiCAL CiviLIZATION}

Primitive agriculture made people transform from the natural collecting cave life and tree dwelling form to a settled life, also called a "habitation". According to archaeological evidence, the settlement of the primitive society was mostly constructed in river terraces or at a higher flat place of the river intersection, adjoining farm fields. Clearly this layout is closely related to the requirements of making full use of rivers to irrigate agricultural production and relying on natural water source to benefit life[1]. Therefore, in the choice of living habitat at that time, people had the initiation of the original sense of the natural environment. However, this awareness is active and spontaneous.

\section{From "Divine Right OF KINGS" TO "INTEGRATION OF HEAVEN AND PEOPLE”}

In the slave society, the low level of productivity made people show respect for "divine right of Kings". This idea emphasizes the destiny of people is controlled by Heaven, which is a thinking tool for the ruling class and it is not the real "harmony between man and nature". But the ruling class complied with public opinions and gradually developed a unique "integration of Heaven and people" thought.

King Wu in Western Zhou dynasty thought: Heaven and earth was the parents of all creatures, and man was the most highly endowed and Heaven's will depended on the wise people to achieve[2]. Although this concept "integration of Heaven and people" in Western Zhou Dynasty is not the real harmony between man and nature, it lays a good foundation and is the direct ideological origin of the Confucian theory[3].

\section{The Idea of Harmonious Coexistence of THE CONFUCIAN "HARMONY BETWEEN MAN AND NATURE"}

The Chinese traditional ancient culture itself includes a philosophical thought of harmonious coexistence between man and nature. This thought is based on Chinese ancient philosophy, which is about the intuition consciousness that man and nature are isogenous, their life essence are unified, and men is one part of nature where they live. Thus, this kind of Chinese ancient holism philosophy is usually summarized as the "harmony between man and nature" idea[4]. The main idea of it is "harmony", which stresses the harmony between man and nature, man and man. But among the ancient philosophers, Confucianism and Taoism are the ones which understood and discussed the harmony values systematically most. 


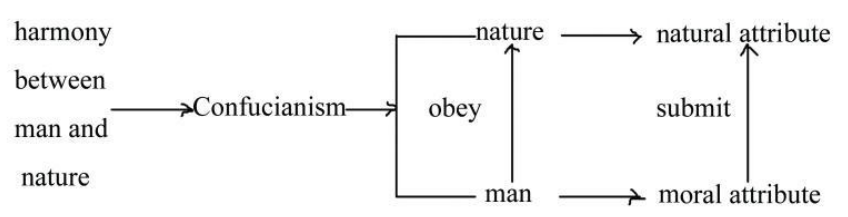

Figure 1. The Confucian theory of harmony between man and nature.

Figure 1 shows the Confucian theory of harmony between man and nature. Confucius advocated that man's kindheartedness should be applied to all things in nature. He also put forward the idea of "The Wise Find Pleasure in Water;

The Virtuous Find Pleasure in Hills", which had a great effect on later generations' environmental culture. But Confucius thought that man is a part of nature and man should obey the law of nature and be kind to nature, so that man and nature can get along well with each other harmoniously[5]. His view of nature is more or less political and limited.

Mencius is another representative of Confucianism. He put forward "good nature" thought, and thought the Heaven has the moral attributes as man, then regarded it as the foundation of the ontology of human ethical morality. So that it realized the true meaning of the unity of Heaven and humanity. He believed that Man is born with good nature and man and all the things come from the same origin. Therefore, the moral attributes of man should not only been applied to the relationship between man, but also should be carried out in the relationship between man and nature to achieve "benevolence for people

and love of the world", so that man can achieve the harmony between man as well as man and nature.

Yi Zhuan is a book which promotes the experience of ancient ancestors and the description of natural phenomena to a systematic philosophy and is the Confucian basic and the highest philosophical classics. In this book, a natural "Heaven" is endowed with human moral and emotion and it is advocated that man should conform to the Heaven and man should get along well with nature is considered rationally. The author believed that this kind of harmony between man and nature can realize the noble personality of Heaven and earth.

Xunzi is a key person in Chinese thought history from pre-Qin to Han Dynasty, whose main idea is "the theory of rituals", inheriting both the thoughts of Confucius and Mencius and inspiring Han-dynasty scholars[6]. He thought that there is similarity and difference between man and nature, so man should know clearly about nature and depend on man themselves to obey and use the law of nature. He also thought that nature is objective and natural.

Xunzi emphasized on human action and stresses practical experience, which requires man to obey objective natural law and think about nature in a rational using way. His thought explains the united and opposite relationship between human and nature. So far, "the unity of man and nature" world view of Confucianism has finished its first stage of development thanks to Xunzi.

\section{V.THE "NONINTERFERENCE" THOUGHT OF TAOISM}

Taoism put forward that "The person reflects the earth. The earth reflects heaven. Heaven reflects the Way. And the Way reflects its own nature.". This is the essence of Taoism to understand the relationship between man and nature, which thinks that all the thoughts and behavior of man should be consistent with law of nature. Meanwhile, man should follow, obey, submit and return to nature; but should not disobey and destroy nature. The Taoist theory advocates that man should give less interference or no interference to the ecological process of natural world so that all living things can develop and evolve naturally, which has an important meaning of environmental protection, and the Taoist theory is shown in Figure 2.

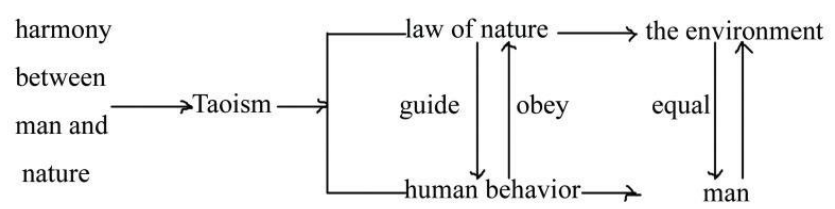

Figure 2. The Taoist theory of harmony between man and nature.

Laozi advocated naturalism and maintained that man should obey and follow the law of nature, objecting the ruling of nature by human beings. Laozi's thought not only emphasizes the harmony of nature and the harmony between men, but also the harmony between nature and man more. He regarded the harmony between man and nature as the basic element for nature to have the ability to create and reproduce everything. All of these profound thoughts are beyond time and space, which can help the modern people to overcome the effect of man's centralism and enhance the consciousness of respecting the law of ecology and advocate moderate consumption, so that they will help reduce the degree of damage to nature.

Zhuangzi maintained the idea that man should respect the natural nature of everything and not destroy the nature of everything[7]. He stressed that man cannot change the nature of everything casually, or tragedy will happen. He also thought that man cannot disobey the law of nature and put forward an idea which is "never destroy nature because of our selfish desire". His ideas warn people to stick to the nature of ego carefully and the law of self-development, which limit man's behavior to a certain limit. Zhuangzi's idea can also be applied to environmental problems that man continue to rob and destroy natural resources wantonly because they only focus on the present profit and selfish desire. If so, it will be inevitable that the eco-system will fall off and man will be extinct along with it. Zhangzi's idea "harmony between Man and Nature" is a main part of aesthetic implication of Chinese traditional culture.

\section{ANALYSIS OF ENVIRONMENT PHILOSOPHY}

The environment philosophy of Confucianism and Taoism has similarities as well as differences. Both of them persisted in "harmony of Man and Nature". They advocated that the mankind should comply with nature and respect nature, pursuing the harmonious coexistence between man 
and nature. Besides, they also claimed that all the living things except human beings need to be cared about from the view of morality. But the Environment philosophy of Confucianism has strong ethical and political thoughts, while Taoism emphasizes naturalism on a large scale. They are shown in the following aspects and Table I.

- Both of them insist the view of "harmony between Man and Nature", but the Confucianism thinks that the law of nature should comply with humanity while Taoism believes that the humanity should obey the law of nature,

- Confucianism focuses on the values of morality,resources and politics of nature; whereas the Taoism puts more emphasis on the value of freedom and aesthetic of nature,

- Both of them appreciate all the creatures,but Confucianism treats them differently while Taoism regards them equally,

- Both of them insist on the harmony between man and nature, but Confucianism emphasizes "joining and developing with nature", while the Taoism claims "Noninterference".

TABLE I. ANALYSIS OF ENVIRONMENT PHILOSOPHY OF CONFUCIANISM AND TAOISM

\begin{tabular}{|c|c|c|c|c|}
\hline $\begin{array}{l}\text { Main } \\
\text { Thoug } \\
\text { ht }\end{array}$ & Groups & $\begin{array}{l}\text { Representa } \\
\text { tive } \\
\text { Figures }\end{array}$ & $\begin{array}{l}\text { Similarit } \\
\text { ies }\end{array}$ & Differences \\
\hline $\begin{array}{l}\text { harmo } \\
\text { ny } \\
\text { betwe } \\
\text { en } \\
\text { man } \\
\text { and } \\
\text { nature }\end{array}$ & $\begin{array}{l}\text { Confucian } \\
\text { ism } \\
\text { Taoism }\end{array}$ & $\begin{array}{l}\text { Conficus, } \\
\text { Mencius, } \\
\text { Xunzi. } \\
\text { Laozi, } \\
\text { Zhuang zi. }\end{array}$ & $\begin{array}{l}\text { world } \\
\text { view as } \\
\text { a whole, } \\
\text { comply } \\
\text { with and } \\
\text { respect } \\
\text { nature, } \\
\text { harmoni } \\
\text { ous } \\
\text { coexiste } \\
\text { nce } \\
\text { between } \\
\text { man and } \\
\text { nature, } \\
\text { moral } \\
\text { concern }\end{array}$ & $\begin{array}{l}\text { Confucianism } \\
\text { thinks that the } \\
\text { law of nature } \\
\text { should comply } \\
\text { with humanity } \\
\text { while Taoism } \\
\text { believes the } \\
\text { humanity } \\
\text { should obey } \\
\text { the law of } \\
\text { nature; } \\
\text { Confucianism } \\
\text { focuses on the } \\
\text { value of } \\
\text { morality, } \\
\text { resources and } \\
\text { politics; } \\
\text { whereas } \\
\text { Taoists puts } \\
\text { more } \\
\text { emphasis on } \\
\text { the value of } \\
\text { freedom and } \\
\text { aesthetic of } \\
\text { nature; } \\
\text { Confucianism } \\
\text { treats them } \\
\text { differently } \\
\text { while Taoism } \\
\text { regards them } \\
\text { equally; } \\
\text { Confucianism } \\
\text { emphasizes } \\
\text { "joining and } \\
\text { developing } \\
\text { with } \\
\text { nature", while } \\
\text { Taoism claims } \\
\text { "Noninterfere } \\
\text { nce" }\end{array}$ \\
\hline
\end{tabular}

\section{INSPIRATION OF MODERN SOCIETY FROM THE ANCIENT THOUGHT}

The ecological crisis brought by modern industrial civilization has become an important factor which restricts the global economy and social development. In order to solve the ecological crisis and achieve sustainable development of mankind, scholars hope that we can draw inspiration from the wisdom of ancient Chinese to obtain best resolution of helping the world. The recipe is exactly the theory of "harmony between man and nature", which can enlighten the aspects of solving the problems of social and economic development and the population, resources and environment as well as the realization of ecological civilization.

(1)abandon the concept of "conquest of nature", and establish the concept of "adaption to the nature"

The values of central-humanism not only did not let the human conquer nature, but get the ruthless revenge of nature. To improve and protect the ecological environment, mankind must realize the harmonious development between human and nature.Human beings should also abandon the concept of "conquering nature" centered on human beings, and set up the values of ecological civilization to adapt to nature. On the basis of respecting and protecting nature, human beings should make reasonable use of nature.

(2)develop a recycling economy and build a resourceconserving society

The shortage of natural resources and the deterioration of ecological environment has become a major factor that restricting the development of social economy, the traditional extensive mode of economic development has made environment and resources overwhelmed, so that the natural ecological system tends to collapse.

Recycling economy is a feedback process, making economic activity into "resources, products, renewable resources", which is based on ecological law to achieve "low mining, high use, low emissions", so that it can maximize the use of substance and energy, improve resource utilization and the quality and efficiency of economic operation to promote the model of economic development "the coordination and harmony of man and nature".

Recycling economy aims to achieve the environmental goal of reducing emissions or even zero emissions of pollutants and finally achieve the ultimate reduction, reuse, recycling through the implementation of reduction, reuse, recycling (3R). The development of Recycling economy is not only beneficial to changing the traditional mode of economic development and achieving the intensive use of resources, but also to building a resource-conserving society and promoting the sustainable development of society.

(3)rely on scientific and technological innovation, and promote the harmonious development of human and nature

The progress of science and technology can effectively promote harmonious development and management level, deepen human understanding of the law of nature, open up the new and available use of natural resources, improve comprehensive utilization efficiency of resources and economic benefit, enhance the effective means to protect the 
natural resources and the ecological environment. These effects are particularly vital to alleviate the contradiction between the Chinese population and economic growth and limited resources,expand the capacity of the environment. Accordingly, they can also expand living space and improve the quality of life, and achieve the strategic goal of sustainable development.

(4)public participation to strengthen environmental management and legal system construction

The harmonious development of human and nature is the fundamental and long-term interests of society. It is not enough to only realize the importance of harmonious development between man and nature.Destruction of resources and environmental pollution are rooted in the motivation of chasing economic interests. In order to stop the behavior of destroying resources and polluting the environment and guarantee the realization of harmonious development between man and nature, we must attach great importance to and vigorously strengthen harmonious development between man and nature in the field of public participation and the construction of legal system.

\section{ACKNOWLEDGMENTS}

Foundation item: National Natural Science Foundation of China(51178168).

\section{REFERENCES}

[1] Y.J.He, History of urban planning in ancient China[M]. China Building Industry Press.Beijing, 2003, pp. 34.

[2] Z.S.Yuan. Shangshu, Duke of Zhou. Taishi, The Four Books and The Five Classics, Vol.1, pp. 406.

[3] Z.Z.Hu and A.Q.Zhao, Introduction to environmental culture[M]. China Environmental Science Press, Beijing, 2008, pp. 24.

[4] C.Q.Lin, On Ecological Ethics in Chinese traditional culture-Based on the perspective of Confucian and Taoist Ethics[J]. Education and Teaching Forum.2014, pp. 5-7.

[5] H.Sheng, The Thought of Ecological Ethics in Chinese Traditional Culture[J]. Journal of Henan University of Science and Technology (Social Science Edition).2009,27(6), pp. 24-27.

[6] Z.H.Li, .History of thought in ancient Chinese[M]. Life/Reading/New knowledge triple Bookstore.Beijing,2008, pp. 107.

[7] D.M.Gao, The harmonious thought in Chinese traditional culture[J]. Qiushi. 2008, pp. 32-34. 